\title{
PENGARUH SISTEM INFORMASI AKUNTANSI TERHADAP PENERIMAAN PAJAK KENDARAAN BERMOTOR DI KANTOR SAMSAT DAN DINAS PENDAPATAN DAERAH KALABAHI KABUPATEN ALOR
}

\author{
${ }^{1)}$ Siti Rahmatia Tambe, ${ }^{2)}$ Herni Sunarya, ${ }^{2)}$ Akbar Yusuf \\ ${ }^{1)}$ Alumnus Program Studi Akuntansi Universitas Muhammadiyah Kupang \\ ${ }^{2)}$ Program Studi A kuntansi Universitas Muhammadiyah Kupang
}

\begin{abstract}
Abstraksi
Penelitian ini bertujuan untuk mengetahui pengaruh sistem informasi akuntansi terhadap penerimaan pajak kendaraan bermotor di Kantor Sistem Administrasi Manunggal Satu Atap dan Dinas Pendapatan Daerah Kalabahi Kabupaten Alor. Sampel penelitian yang digunakan sebanyak 35 pegawai pada Kantor Sistem Administrasi Manunggal Satu Atap dan Dinas Pendapatan Daerah Kalabahi Kabupaten Alor. Teknik analisis yang digunakan pada penelitian ini adalah analisis regresi berganda. Hasil penelitian menunjukan bahwa secara parsial kepuasan pengguna sistem informasi akuntansi berpengaruh signifikan terhadap penerimaan pajak kendaraan bermotor. Sedangkan untuk penggunaan sistem informasi akuntansi dan dukungan manajemen puncak tidak terbukti berpengaruh signifikan terhadap penerimaan pajak kendaraan bermotor. Pengujian secara simultan menunjukan kepuasan pengguna sistem informasi akuntansi, penggunaan sistem informasi akuntansi dan dukungan manajemen puncak berpengaruh signifikan terhadap penerimaan pajak kendaraan bermotor.
\end{abstract}

Kata Kunci : Sistem Informasi Akuntansi, Dukungan Manajemen Puncak, Penerimaan Pajak Kendaraan Bermotor.

\section{PENDAHULUAN}

Penerimaan pajak di Indonesia masih cukup rendah. Hal ini disebabkan masyarakat yang pasif dalam membayar pajak. Mardiasmo (2009:8) mengatakan bahwa masyarakat enggan (pasif) membayar pajak disebabkan; perkembangan intelektual dan moral masyarakat, sistem perpajakan yang mungkin sulit dipahami masyarakat, serta sistem kontrol tidak dapat dilaksanakan dengan baik. Untuk itu pemahaman tentang sistem harus diterapkan pada masyarakat seperti sistem informasi akuntansi yang menggunakan tiga indikator ukuran efektifitas sistem diantaranya; kepuasan pengguna, penggunaan sistem informasi dan dukungan manajemen puncak dan juga kekhawatiran masyarakat dalam membayar pajak disebabkan pajak yang telah dibayar disalahgunakan oleh aparat pajak itu sendiri.

Setiap orang membutuhkan fasilitas untuk menjalani aktifitas hidup agar efisien dan efektif, seperti halnya transportasi kendaraan beroda dua ataupun lebih yang akan mempermudah orang dari satu tempat ke tempat lain. Masyarakat dalam hal ini wajib pajak yang memiliki kendaraan bermotor diwajibkan untuk membayar pajak kendaraan bermotor. Salah satu jenis pajak yang memiliki potensi yang semakin meningkat seiring dengan kemajuan teknologi dan standar kebutuhan sekunder menjadi primer adalah pajak kendaraan bermotor, Ratnasari (2016).

Kemajuan dalam bidang teknologi telah mengubah cara orang dalam melaksanakan semua aktifitasnya. Perkembangan sistem teknologi informasi berdampak pada sistem 
informasi akuntansi dalam organisasi bisnis dari pemrosesan data pada sistem manual ke sistem komputer secara efektif dan efisien, Jumaili (2005) dalam Mahadinata et. al. (2016). Sistem manualnya seperti wajib pajak saat membayar pajak masih menggunakan sistem pencatatan manual sehingga menjadi terhambat dan lama pekerjaan yang dilakukan oleh pegawai, untuk itu perubahan sistem harus diikuti untuk menunjang membantunya segala aktivitas seperti pembayaran pajak yang sudah menggunakan sistem komputer sehingga wajib pajak saat membayar pajak tidak ada hambatan dalam proses pelayanan.

Salah satu syarat untuk dapat berkomputerisasi adalah penyediaan suatu sistem informasi akuntansi yang cepat, tepat dan akurat sehingga perusahaan atau organisasi dapat mengambil keputusan yang cepat dan tepat pula. Penerapan teknologi dalam sistem informasi perusahaan hendaknya mempertimbangkan pemakai sistem sehingga teknologi yang diterapkan dapat bermanfaat sesuai dengan tugas dan kemampuan pemakai. Keberhasilan sistem informasi suatu perusahaan tergantung bagaimana sistem itu dijalankan, kemudahan sistem itu bagi para pemakainya, dan pemanfaatan teknologi yang digunakan, Montazemi (1989) dalam Istianingsih (2007).

Sistem informasi akuntansi memiliki beberapa faktor yang menjadi dasar pengukuran keberhasilan sistem informasi seperti; kepuasan pengguna, penggunaan sistem informasi dan dukungan manajemen puncak. Kepuasan pengguna terhadap suatu sistem informasi adalah bagaimana cara pemakai memandang sistem informasi secara nyata, tapi tidak pada kualitas sistem secara teknik menurut Guimaraes et. al. (2003) dalam Istianingsih (2007). Dalam konteks ini seringkali memasukkan opini dari para pengguna tentang akurasi, ketepatan waktu, relevansi informasi, kualitas pelayanan yang diberikan, dan jadwal operasi menjadi sangat penting, pengguna akan lebih merasa bahwa mereka turut serta dalam pengawasan dan memiliki sistem.

Penggunaan sistem informasi tentunya berharap bahwa dengan menggunakan sistem tersebut mereka akan memperoleh informasi yang mereka butuhkan. Dukungan manajemen puncak merupakan pihak yang bertanggungjawab atas penyediaan pedoman umum bagi kegiatan sistem informasi, dan tingkat dari dukungan yang diberikan oleh manajemen puncak tersebut bagi sistem informasi organisasi dapat menjadi suatu faktor yang sangat penting dalam menentukan keberhasilan semua kegiatan yang berkaitan dengan sistem informasi, Hasmi (2004) dalam Septianingrum (2014).

Sistem menurut Mulyadi (2002) dalam Suratini et. al. (2015)"sistem merupakan suatu jaringan prosedur yang dibuat menurut pola yang terpadu untuk melaksankan kegiatan pokok perusahaan. Sedangkan Romney dan Steinbart (2006:3) mengungkapkan bahwa sistem adalah rangkaian dari dua atau lebih komponen-komponen yang saling berhubungan, yang berinteraksi untuk mencapai suatu tujuan. Menurut Jerry Fitzgrald (2011) dalam Puspitawati \& Anggadini (2011:1) Sistem adalah suatu jaringan kerja dari prosedur-prosedur yang saling berhubungan, berkumpul bersama-sama untuk melakukan suatu kegiatan atau untuk menyelesaikan suatu sasaran yang tertentu. Menurut Diana dan Setiawati (2011:3) mengatakan sistem merupakan serangkaian bagian yang saling bergantung dan bekerja sama untuk mencapa tujuan tertentu. Dengan demikian sekelompok elemen atau prosedur yang erat berhubungan satu dengan lainnya, yang berfungsi bersama-sama untuk mencapai tujuan tertentu, seperti prosedur baik manual maupun yang terkomputerisasi untuk penerimaan data. Sistem penerimaan merupakan 
suatu kegiatan yang dilakukan oleh organisasi yang dilibatkan dalam cara mengumpulkan, memproses dan menyimpan data tentang aktivitas-aktivitas organisasi dalam mencapai tujuan.

Sistem informasi akuntansi penerimaan pajak kendaraan bermotor merupakan sistem berbasis komputer yang dirancang untuk mentransformasi data akuntansi menjadi informasi, yang mencakup siklus pemrosesan transaksi seperti (pembayaran pajak kendaraan bermotor, bea balik nama kendaraan bermotor, dan sumbangan wajib dana kecelakaan lalu lintas jalan, serta pengesahan STNK). Menurut Romney \& Steinbart (2006:3) menjelaskan bahwa terdapat lima komponen dalam sistem informasi akuntansi, yaitu: (a) orang-orang, (b) prosedur-prosedur, (c) data, (d) software, (e) infrastruktur teknologi informasi.

Demikian juga Samsat dan Dinas Pendapatan Daerah Kalabahi Kabupaten Alor memerlukan suatu sistem informasi akuntansi yang berkualitas sehingga dapat mencapai penerimaan pajak kendaraan bermotor yang maksimal dan tercapainya tujuan organisasi.

Adapun penelitian terdahulu oleh Syafariani (2005) meneliti tentang pengaruh penerapan sistem informasi akuntansi terhadap akuntabilitas pendapatan pajak daerah menunjukan bahwa penerapan sistem informasi akuntansi pada dinas pendapatan menunjukan kriteria baik. Akuntabilitas pendapatan pajak sudah termasuk dalam kategori baik. Febriati (2011) meneliti tentang Analisis sistem pengendalian pemungutan pajak kendaraan bermotor dalam peningkatan PAD menunjukan bahwa luas wilayah Kota Singkawang yang menyebabkan target penerimaan belum mencapi karena keterlambatan dalam proses pelaporan dari wajib pajak dan tingkat kesadaran wajib pajak yang masih kurang dalam tata cara pemungutan.Indra Purnama Saefulloh (2013) tentang Perancangan sistem informasi pembayaran pajak kendaraan beroda dua menunjukan dengan dibuatkannya rancangan sistem informasi pembayaran pemanggilan input dari penetapan SKPD maka akan mempermudah dan mempercepat proses dibagian pembayaran sehingga tidak ada kekeliruan dalam nominal jumlah yang dibayar serta mempermudah merekap data laporan hasil transaksi pembayaran pajak. Mulyawan dan Novia (2016) tentang Aplikasi pembayaran Pajak kendaraan bermotor online berbasis web memberikan empirik bahwa aplikasi ini dapat mempermudah dalam penyusunan dan proses perhitungan pajak dengan cepat dan akurat.

Berdasarkan latar belakang diatas, maka peneliti melakukan penelitian dengan judul pengaruh sistem informasi akuntansi terhadap penerimaan pajak kendaraan bermotor sehingga variabel bebasnya kepuasan pengguna sistem informasi akuntasi, penggunaan sistem informasi akuntansi, dukungan manajemen puncak mempengaruhi variabel terikatnya penerimaan pajak kendaraan bermotor.

\section{TINJAUAN PUSTAKA}

\section{Sistem Informasi A kuntansi}

Nugroho Widjajanto (2001) dalam Umi (2011), mendefinisikan sistem adalah sesuatu yang memiliki bagian-bagian yang saling berinteraksi untuk mencapai tujuan tertentu melalui tiga tahapan yaitu input, proses dan output. Romney dan Steinbart (2006:2) mengungkapkan bahwa sistem adalah rangkaian dari dua atau lebih komponen-komponen yang saling berhubungan, yang berinteraksi untuk mencapai suatu tujuan. 
Menurut Puspitawai dan Anggadini (2011) ciri-ciri sistem ada beberapa yaitu: a) Tujuan sistem; b) Batas sistem; c) Subsistem; d) Hubungan dan herarki sistem; dan e) Input- proses-output.

Menurut Gordon B. Davis (2011) dalam Frengky (2014), informasi adalah data yang telah diolah menjadi sebuah bentuk yang berarti bagi penerimanya dan bermanfaat dalam mengambil keputusan saat ini atau mendatang. Menurut Puspitawati dan Anggadini (2011:13), informasi adalah data yang diolah menjadi bentuk yang lebih berguna dan lebih berarti dalam menerimanya.

Berdasarkan pengertian informasi yang disebutkan di atas dapat disimpulkan bahwa informasi adalah data yang diolah atau dibentuk menjadi bentuk lebih berguna dan manfaat bagi orang yang menerimanya dan dapat digunakan sebagai alasan untuk melakukan suatu tindakan serta mengambil keputusan.

Puspitawati dan Anggadini, suatu informasi yang berkualitas mempunyasi ciri-ciri yaitu:

a. Akurat artinya informasi harus mencerminkan keadaan yang sebenarnya, artinya informasi bebas dari kesalahan tidak bias ataupun menyesatkan, akurat dapat diartikan bahwa informasi itu dapat dengan jelas mencerminkan maksudnya; dan

b. Tepat waktu artinya informasi harus tersedia pada saat informasi tersebut diperlukan. Informasi yang datang pada penerima tidak boleh terlambat. Di dalam pengambilan keputusan, informasi yang sudah usang tidak lagi ada nilainya, apabila informasi terlambat datang sehingga pengambilan keputusan terlambat dilakukan hal tersebut dapat berakibat fatal bagi perusahaan.

Bodnar dan Hopwood (2004:8) sistem informasi akuntansi adalah sistem berbasis komputer yang dirancang untuk mentransformasi data akuntansi menjadi informasi serta mencakup juga siklus pemrosesan transaksi, pengguna teknologi informasi, dan pengembangan sistem informasi. Menurut Romney dan Steinbart (2006:3) mengatakan sistem informasi akuntansi terdiri dari lima komponen yaitu: orang, prosedur, data, software, dan infrastruktur teknologi informasi. Kelima komponen ini secara bersamasama memungkin suatu SIA memenuhi tiga fungsi pentingnya dalam organisasi, yaitu:

1) Mengumpulkan dan menyimpan data tentang aktivitas-aktivitas yang dilaksanakan oleh organisasi, sumber daya yang dipengaruhi oleh aktivitas-aktivitas tersebut, dan para pelaku yang terlibat dalam berbagai aktivitas tersebut, agar pihak manajemen, para pegawai, dan pihak-pihak luar yang berkepentingan dapat meninjau ulang (review) hal-hal yang telah terjadi;

2) Mengubah data menjadi informasi yang berguna bagi pihak manajemen untuk membuat keputusan dalam aktivitas perencanaan, pelaksanaan, dan pengawasan; dan

3) Menyediakan pengendalian yang memadai untuk menjaga aset-aset organisasi, termasuk data organisasi, untuk memastikan bahwa data tersebut tersedia saat dibutuhkan, akurat, dan andal.

Berdasarkan pengertian menurut beberapa para ahli, maka disimpulkan bahwa sistem informasi akuntansi merupakan sistem yang mengumpulkan dan memproses data transaksi, menyajikan informasi keuangan kepada pihak-pihak yang berkepentingan serta melibatkan beberapa komponen yag terdiri dari orang, prosedur, data, software dan insfrastruktur teknologi informasi dalam mengoperasikan sistem serta memproses data dalam organisasi. 


\section{Kepuasan pengguna}

Kepuasan pemakai terhadap suatu sistem informasi adalah bagaimana cara pemakai memandang sistem informasi secara nyata, tapi tidak pada kualitas sistem secara teknik (Guimaraes, Staples, dan McKeen, 2003) dalam Istianingsih (2007). Kepuasan para pengguna terhadap sistem (users satisfaction with the systems) yang diterapkan. Dalam konteks ini seringkali memasukkan opini dari para pengguna tentang akurasi, ketepatan waktu, relevansi informasi, kualitas pelayanan yang diberikan, dan jadwal operasi menjadi sangat penting. Selain itu, hasil akhir dari suatu sistem akan mencerminkan persyaratan-persyaratan yang harus dipenuhi oleh pengguna. Pengguna akan lebih merasa bahwa mereka turut serta dalam pengawasan dan memiliki sistem. Pengguna juga merasa lebih puas dengan sistem informasi jika mereka dilatih untuk menggunakan sistem secara tepat. Dengan demikian, dukungan pengguna dalam implementasi sistem memiliki peranan dalam menunjang keberhasilan sistem informasi itu sendiri, menurut Husein dan Wibowo (2000) dalam Istianingsih (2007).

\section{Penggunaan Sistem Informasi}

Seddon dan Kiew (1996) dalam Istianingsih (2007), pengguna sistem informasi tentunya berharap bahwa dengan menggunakan sistem tersebut mereka akan memperoleh informasi yang mereka butuhkan. Karakteristik informasi yang dihasilkan suatu sistem informasi tertentu, dapat saja berbeda dengan informasi dari sistem informasi yang lain. Sistem informasi yang mampu menghasilkan informasi yang tepat waktu, akurat, sesuai kebutuhan, dan relevan serta memenuhi kriteria dan ukuran lain tentang kualitas informasi, akan berpengaruh terhadap kepuasan pemakainya. Semakin tinggi kualitas informasi yang dihasilkan suatu sistem informasi, diprediksi akan berpengaruh terhadap semakin tingginya kepuasan pengguna akhir suatu sistem informasi.

\section{Dukungan Manajemen Puncak}

Dukungan manajemen puncak merupakan pihak yang bertanggungjawab atas penyediaan pedoman umum bagi kegiatan sistem informasi, dan tingkat dari dukungan yang diberikan oleh manajemen puncak tersebut bagi sistem informasi organisasi dapat menjadi suatu faktor yang sangat penting dalam menentukan keberhasilan semua kegiatan yang berkaitan dengan sistem informasi, Hasmi (2004) dalam Septianingrum (2014).

Pengetahuan manajer akuntansi terhadap sistem informasi juga merupakan faktor yang tidak kalah penting dalam aplikasi serta pengembangan sistem informasi akuntansi . Komala (2012) dalam Ratnaningsih (2014) menyatakan bahwa manajer akuntansi (controller) merupakan eksekutif yang mengkoordinasikan partisipasi manajemen dalam perencanaan dan pengendalian untuk mencapai target perusahaan, khususnya untuk menentukan efektivitas implementasi kebijakan dan mengembangkan struktur dan prosedur organisasi. Manajer akuntansi merupakan eksekutif tertinggi yang memiliki tanggung jawab atas keberlangsungan segala aktivitas dalam departemen akuntansi. Tanggung jawab besar yang dijalankan menuntut seorang manajer akuntansi untuk memiliki pengetahuan yang tinggi terhadap implementasi sistem informasi akuntansi. Keluaran yang dihasilkan dari sistem informasi akuntansi adalah berupa laporan keuangan yang akan diserahkan kepada pihak manajemen dan akan digunakan sebagai alat pengambilan keputusan. 


\section{Pajak Kendaraan Bermotor (Pkb)}

Siahan (2010:175) kendaraan bermotor adalah semua kendaraan beroda dua atau lebih, beserta gandengannya yang digunakan disemua jenis jalan darat dan digerakan oleh peralatan teknik, berupa motor atau peralatan lain yang berfungsi untuk mengubah suatu sumber daya energi tertentu menjadi tenaga. Sedangkan pajak kendaraan bermotor adalah pajak atas kepemilikan dan/atau penguasaan kendaraan bermotor.

Siahan (2010:182) objek pajak kendaraan bermotor adalah kepemilikan dan atau penguasaan kendaraan bermotor. Kendaraan bermotor adalah semua kendaraan beroda beserta gandengannya yang digunakan disemua jenis jalan darat, dan digerakan oleh peralatan teknik berupa motor atau peralatan lainnya yang berfungsi untuk mengubah suatu sumber daya energi tertettu menjadi tenaga gerak kendaraan bermotor yang bersangkutan.

Wajib pajak adalah orang pribadi atau badan yang memiliki kendaraan bermotor, jika wajib pajak merupakan badan maka kewajiban perpajakannya diwakili oleh pengurus atau kuasa hukum badan tersebut. Dengan demikian, pada PKB subjek pajak sama dengan wajib pajak, yaitu orang pribadi atau badan yang memiliki atau menguasai kendaraan bermotor.

Tungka dan Sabijono (2015) subjek pajak adalah orang pribadi atau badan yang memiliki dan atau menguasai kendaraan bermotor. Sementara itu, yang menjadi wajib pajak adalah orang pribadi atau badan yang memiliki kendaraan bermotor. Jika wajib pajak berupa badan, kewajiban perpajakannya diwakili oleh pengurus atau kuasa badan tersebut, dengan demikian pada PKB subjek pajak sama dengan wajib pajak, yaitu orang pribadi atau badan yang memiliki dan menguasai kendaran bermotor.

Dalam menjalankan kewajiban perpajakannya, wajib pajak dapat diwakili oleh pihak tertentu yang diperkenankan oleh undang-undang dan peraturan daerah tentang PKB. Wakil wajib pajak bertanggungjawab secara pribadi atau secara tanggung rentang atas pembayaran pajak terutang. Selain itu, wajib pajak dapat menunjuk seorang kuasa dengan surat kuasa khusus untuk menjalankan hak dan memenuhi kewajiban perpajakannya.

\section{Sistem Informasi Akuntansi Penerimaan Pajak Kendaraan Bermotor}

Sistem penerimaan sama halnya dengan pendapatan yaitu sistem informasi akuntansi sebagaimana dikemukakan oleh Bodnar dan Hopwood (2004:8) adalah sistem berbasis komputer yang dirancang untuk mentransformasi data akuntansi menjadi informasi serta mencakup juga siklus pemrosesan transaksi, pengguna teknologi informasi, dan pengembangan sistem informasi. Proses transaksinya seperti pembayaran pajak kendaraan bermotor, bea balik nama kendaraan bermotor dan sumbangan wajib dana kecelakaan lalu lintas jalan. Ini merupakan penerimaan dalam pajak kendaraan bermotor itu sendiri sehingga membutuhkan peran sistem informasi akuntansi.

Standar Akuntansi Keuangan (SAK) No. 23 (2002) dalam Agustina (2015), mengatakan pendapatan adalah arus masuk bruto dari manfaat-manfaat ekonomi yang timbul dari aktivitas-aktivitas normal perusahaan selama suatu periode bila arus masuk tersebut mengakibatkan kenaikan ekuitas, yang tidak berasal dari kontribusi penanaman modal. 


\section{Kerangka Berpikir Dan Hipotesis}

Romney \& Steinbart (2006:3) menjelaskan bahwa terdapat lima komponen dalam sistem informasi akuntansi, yaitu: (a) orang-orang yang mengoperasikan sistem tersebut dalam melaksanakan berbagai fungsi, (b) prosedur-prosedur, baik manual maupun yang terorganisasi yang melibatkan dalam pengumpulan, memproses, dan menyimpan data, (c) data tentang prosedur-prosedur bisnis organisasi, (d) software yang dipakai untuk memproses data organisasi, (e) infrastruktur teknologi informasi, termasuk komputer, peralatan pendukung dan peralatan komunikasi jaringan. Dalam penelitian ini peneliti menggunakan komponen orang-orang yang mengoperasikan sistem informasi akuntansi dalam melaksanakan berbagai tugas atau pekerjaannya. Secara umum sistem informasi akuntansi berhubungan dengan penerimaan pajak. Hal ini didukung oleh sejumlah penelitian. Penelitian Syafariani dan Feryani (2005) menjelaskan bahwa terdapat hubungan yang erat dan searah antara sistem informasi akuntansi dengan akuntabilitas pendapatan pajak. Hasil penelitian Stanley (2014) menunjukkan bahwa sistem akuntansi UKM memiliki hubungan positif yang signifikan dengan sistem administrasi pajak. Penelitian Altarwneh, et al. (2015) sistem informasi komputer mempengaruhi dalam pengurangan penggelapan pajak.

Berdasarkan hubungan variabel di atas dapat digambarkan suatu kerangka pemikiran seperti gambar 1 dibawah ini:

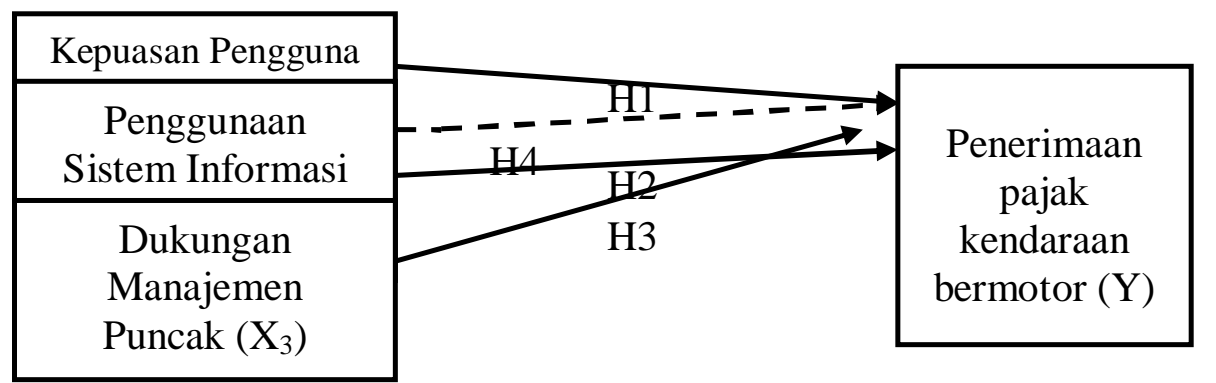

Keterangan:

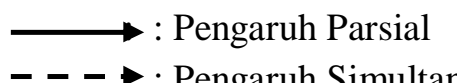

Gambar 1: Kerangka Berpikir (Sumber: Olahan Penulis, 2017)

\section{Hipotesis Penelitian}

H1: Kepuasan pengguna sistem informasi akuntansi berpengaruh signifikan terdahap penerimaan pajak kendaraan bermotor.

H2: Penggunaan sistem informasi akuntansi berpengaruh signifikan terhadap penerimaan pajak kendaraan bermotor.

H3: Dukungan manajemen puncak berpengaruh signifikan terhadap penerimaan pajak kendaraan bermotor.

H4: Kepuasan pengguna sistem informasi akuntansi, penggunaan sistem informasi akuntansi dan dukungan manajemen puncak berpengaruh signifikan secara simultan terhadap penerimaan pajak kendaraan bermotor. 


\section{METODELOGI PENELITIAN}

Desain penelitian adalah suatu bentuk rancangan tentang hubungan antara variabel yang diteliti sehingga dapat memberikan suatu gambaran untuk menjawab pertanyaan atau menguji hipotesis penelitian. Menurut Mansoer (2006:139) desain penelitian adalah rancangan umum tentang metode-metode dan prosedur-prosedur untuk mengumpulkan dan menganalisis informasi yang dibutuhkan. Hal ini menjelaskan suatu penelitian diharapkan memenuhi tahapan dan metode yang sesuai dengan variabel yang ingin diungkap. Sedangkan pendekatan penelitian ini menggunakan pendekatan cross sectional yaitu penelitian yang dilakukan satu waktu dan satu kali.

Tipe penelitian ini adalah tipe penelitian deskriptif kuantitatif dengan menggunakan metode penelitian survei, karena penelitian ini bermaksud menjelaskan pengaruh atau hubungan antara variabel sistem informasi akuntansi terhadap penerimaan pajak kendaraan bermotor. Lokasi penelitian ini akan dilakukan di Kantor Samsat dan Kantor Dinas Pendapatan Daerah Kalabahi Kabupaten Alor dan waktu penelitian yaitu dilaksanakan kurang lebih 1 bulan.

\section{A. POPULASI DAN SAMPEL}

Populasi dalam penelitian ini adalah seluruh pegawai kantor samsat di kabupaten Alor yang berjumlah 12 orang dan seluruh pegawai pada Dinas Pendapatan Daerah Kabupaten Alor yang berjumlah 110 orang. Sedangkan sampel dalam penelitian ini adalah pegawai samsat berjumlah 12 orang dan pegawai Dispenda yang bekerja pada bagian seksi penerimaan berjumlah 23 orang, sehingga jumlah sampel dalam penelitian ini adalah 35 orang.

Teknik pengambilan sampel yang digunakan dalam penelitian ini adalah purposive sampling. Menurut Sugiyono (2014:85) purposive Sampling adalah teknik penentuan sampel dengan pertimbangan tertentu. Maka sampel yang dipilih pada penelitian ini adalah kriteria pegawai yang bekerja pada kantor atau pada bidang penerimaan pajak kendaraan bermotor.

\section{B. TEKNIK PENGUMPULAN DATA}

Guna memperoleh informasi data yang dibutuhkan dalam penulisan proposal penelitian ini, maka peneliti menggunakan metode kuesioner. Metode kuesioner adalah sejumlah data/pernyataan tertulis yang digunakan untuk memperoleh informasi dari responden. Peneliti menggunakan teknik ini untuk mendapatkan data tentang sistem informasi akuntansi penerimaan pajak kendaraan bermotor. Dalam penelitian ini peneliti menggunakan angket langsung dengan bentuk rating-scak, dimana daftar pertanyaanpernyataan ditanggapi langsung oleh responden sendiri dengan memilih jawaban yang sesuai dengan apa yang didapatkan responden dari organisasi. Pertanyaan-pertanyaan yang diajukan berdasarkan aspek yang tertuang dalam indikator yang telah disusun. Untuk menentukan nilai jawaban angket dari masing-masing pertanyaan yang diajukan dengan modifikasi skala likert.

\section{DEFINISI OPERASIONAL DAN PENGUKURAN VARIABEL}

Variabel bebas dalam penelitian adalah sistem informasi akuntansi yang diukur dengan menggunakan tiga indikator ukuran efektivitas, Almalia (2007) dalam Ajeng (2015) yakni; kepuasan pengguna sistem informasi akuntansi, penggunaan sistem informasi akuntansi dan dukungan manajemen puncak. 
a. Kepuasan pengguna (masyarakat/wajib pajak) sistem informasi akuntansi $\left(\mathrm{X}_{1}\right)$ yaitu gambaran dari kesuksesan pada sistem informasi yang dihubungkan kepada elemen pembentuk kesuksesan dalam beberapa aspek empiris dan konseptual, Bailey dan Sammi (1983) dalam Ary (2013) yang diukur dengan lima indikator atau item kuesioner yang dikembangkan dari Torkzadeh dan Doll (1999) yaitu: kelengkapan isi, keakuratan, tampilan, kemudahan dan ketepatan;

b. Penggunaan (pegawai SAMSAT dan DISPENDA) sistem informasi akuntansi $\left(\mathrm{X}_{2}\right)$ yaitu penggunaan sistem yang dilihat dari perilaku seorang individu yang menggunakan sistem itu karena adanya manfaat yang akan diperoleh untuk membantu dalam menyelesaikan pekerjaannya, Soegiharto (2001) dalam Ajeng (2015) yang diukur dengan tiga indikator atau item kuesioner yang dikembangkan dari Choe (1996) yaitu: kemudahan dalam memahami sistem informasi, keakuratan layanan sistem informasi dan ketepatan layanan sistem informasi; dan

c. Dukungan manajemen puncak $\left(\mathrm{X}_{3}\right)$ yaitu pemahaman manajemen puncak tentang sistem komputer dan tingkat minat, dukungan, dan pengetahuan tentang SI atau komputerisasi, Tjhai (2002) dalam Hendra et al (2014) yang diukur dengan dua indikator atau item kuesioner yang diadopsi dalam Amri (2009) yaitu pengembangan sistem informasi dan operasi serta pengembangan formalisasi sistem informasi.

Variabel terikat dalam penelitian adalah penerimaan pajak kendaraan bermotor dengan menggunakan dua indikator yang diadopsi dari Winarso (2015) yakni; target penerimaan pajak kendaraan bermotor dan jumlah pembayar pajak kendaraan bermotor.

a. Target penerimaan pajak kendaraan bermotor yaitu, Anggraini et al (2016) menggunakan teori harapan untuk melihat penerimaan pajak kendaraan bermotor yaitu sesuatu yang membuat seseorang atau kelompok akan termotivasi untuk melakukan sesuatu hal dalam upaya mencapai suatu tujuan tertentu. Dari pengertian diatas dapat disimpulkan bahwa jika pihak Dinas pendapatan daerah (DISPENDA) menginginkan pencapaian target dalam penerimaan pajak, maka DISPENDA akan meningkatkan kualitas pelayanan pemungutan PKB terutama dalam menertibkan wajib pajak yang belum membayar kewajiban pajaknya, begitu pula sebaliknya. Indikator ini diadopsi dalam Winarso (2015).

b. Jumlah pembayar pajak kendaraan bermotor yaitu, Ratnasari (2016) menjelaskan masyarakat dalam hal ini wajib pajak yang memiliki kendaraan bermotor diwajibkan untuk membayar pajak sesuai dengan jumlah yang telah ditetapkan. Indikator ini diadopsi dalam Winarso (2015).

\section{UJI VALIDITAS DAN RELIABILITAS}

Uji validitas dapat dihitung dengan cara membandingkan nilai $\mathrm{r}$ hitung (correlation item total correlation) dengan nilai $\mathrm{r}$ tabel dengan ketentuan untuk degree of freedom $(\mathrm{df})=\mathrm{n}-\mathrm{k}$ (Sugiyono, 2014:128), dimana $\mathrm{n}$ adalah jumlah sampel dan $\mathrm{k}$ adalah jumlah variable independen. Bila $r$ hitung $>r$ tabel, berarti pernyataan tersebut dinyatakan valid. $\mathrm{R}$ hitung $<\mathrm{r}$ tabel, berarti pernyataan tersebut dinyatakan tidak valid. Sementara uji reliabilitas merujuk pada kemampuan suatu instrument untuk diuji kembali dengan memberikan hasil yang relative constant. Artinya suatu instrument dikatakan reliable jika 
instrument itu memberikan hasil yang relative sama jika diuji secara berulang-ulang. Pada studi ini, pengujian reliabilitas akan menggunakan koefisien alpha cronbach.

\section{E. TEKNIK ANALISA DATA}

\section{Deskriptif statistik}

Deskriptif statistik memberikan gambaran atau deskripsi suatu data yang dilihat dari nilai rata-rata (mean), standar deviasi, maksimum, minimum, Ghozali (2011) dalam Yusuf (2013).

\section{Uji asumsi klasik}

Sebuah model regresi akan digunakan untuk melakukan peramalan, sebuah model yang baik adalah model dengan kesalahan peramalan yang seminimal mungkin. Oleh karena itu, sebuah model sebelum digunakan seharusnya memenuhi beberapa asumsi, yang disebut dengan asumsi klasik (Santoso, 2011) dalam (Rosi 2016). Uji asumsi klasik dalam penelitian ini mencakup uji normalitas, uji multikolinieritas dan uji heteroskedastisitas.

\section{F. PENGUJIAN HIPOTESIS}

Pengujian hipotesis menggunakan teknik analisis regresi berganda, sebagai berikut: $\mathrm{Y}=\mathrm{a}+\beta_{1} \mathrm{X}_{1}+\beta_{2} \mathrm{X}_{2}+\beta_{3} \mathrm{X}_{3}+\mathrm{e}$.

\section{G. HASIL PENELITIAN DAN PEMBAHASAN}

1) Uji Validitas dan Reliabilitas

Berdasarkan hasil analisis SPSS 16 menunjukkan bahwa instrument untuk semua variabel dalam penelitian adalah valid, sehingga semua item dapat digunakan sebagai alat untuk pengumpulan data. Pada studi ini, pengujian reliabilitas menggunakan koefisien alpha cronbach. Hasil uji menggunakan SPSS menunjukkan bahwa semua pernyataan adalah reliabel, sehingga penelitian ini dapat dilanjutkan.

\section{2) Deskripsi Statistik}

Berdasarkan hasil kuesioner yang telah diedarkan pada pegawai Kantor SAMSAT dan DISPENDA Kalabahi Kab. Alor, yang sudah terkumpul untuk tujuan analisis data yang berkaitan dengan variabel Kepuasan Pengguna SIA $\left(x^{1}\right)$, Penggunaan SIA $\left(\mathrm{x}^{2}\right)$, Dukungan Manajemen Puncak $\left(\mathrm{x}^{3}\right)$, berdampak pada Penerimaan PKB (y). Data tersebut diolah dengan menggunakan SPSS versi 16 for windows yang menghasilkan statistik deskriptif yang terdapat nilai minimum, maximum, mean (rata-rata) dan standar deviasi.

Tabel 6. Statistik Deskriptif

\begin{tabular}{lccccc}
\hline & N & Minimum & Maximum & Mean & $\begin{array}{c}\text { Std. } \\
\text { Deviasi }\end{array}$ \\
\hline $\begin{array}{l}\text { Kepuasan Pengguna } \\
\text { SIA }\end{array}$ & 35 & 57,00 & 75,00 & 62,8857 & 5,31796 \\
\hline Penggunaan SIA & 35 & 33,00 & 45,00 & 36,2571 & 3,22985 \\
\hline $\begin{array}{l}\text { Dukungan Manajemen } \\
\text { Puncak }\end{array}$ & 35 & 19,00 & 25,00 & 20,8857 & 1,51019 \\
\hline Penerimaan PKB & 35 & 22,00 & 29,00 & 26,9143 & 2,33101 \\
\hline
\end{tabular}

Sumber: Data Primer, diolah SPSS versi 16 Tahun 2017 
Berdasarkan output SPSS di atas menunjukkan bahwa jumlah responden $(\mathrm{N})$ adalah sebanyak 35 responden, 35 responden ini memberikan persepsi terendah (minimum) terhadap variabel kepuasan pengguna sistem informasi akuntansi adalah sebesar 57 point, dan persepsi tertinggi (maximum) responden adalah sebesar 75 point, rata-rata (mean) persepsi responden (dari 35 responden) adalah sebesar 62,88 point dengan standar deviasi (SD) sebesar 5,31 point. Variabel penggunaan sistem informasi akuntansi persepsi terendah (minimum) adalah sebesar 33 point, dan persepsi tertinggi (maximum) sebesar 45 point, rata-rata (mean) sebesar 36,25 point dengan standar deviasi (SD) sebesar 3,22 point. Variabel dukungan manajemen puncak persepsi terendah (minimum) adalah sebesar 19 point, dan persepsi tertinggi (maximum) sebesar 25 point, rata-rata (mean) sebesar 20,88 point dengan standar deviasi (SD) sebesar 1,51 point. Variabel penerimaan pajak kendaraan bermotor persepsi terendah (minimum) adalah sebesar 22 point, dan persepsi tertinggi (maximum) sebesar 22 point, rata-rata (mean) sebesar 26,91 point dengan standar deviasi (SD) sebesar 2,33 point.

\section{B. Uji Regresi Berganda}

Setelah model penelitian ini dinyatakan lolos asumsi klasik, maka dapat digunakan untuk menguji hipotesis penelitian ini. Hasil regresi dari pengolahan data adalah sebagai berikut:

Tabel 9. Hasil Uji Regresi Berganda

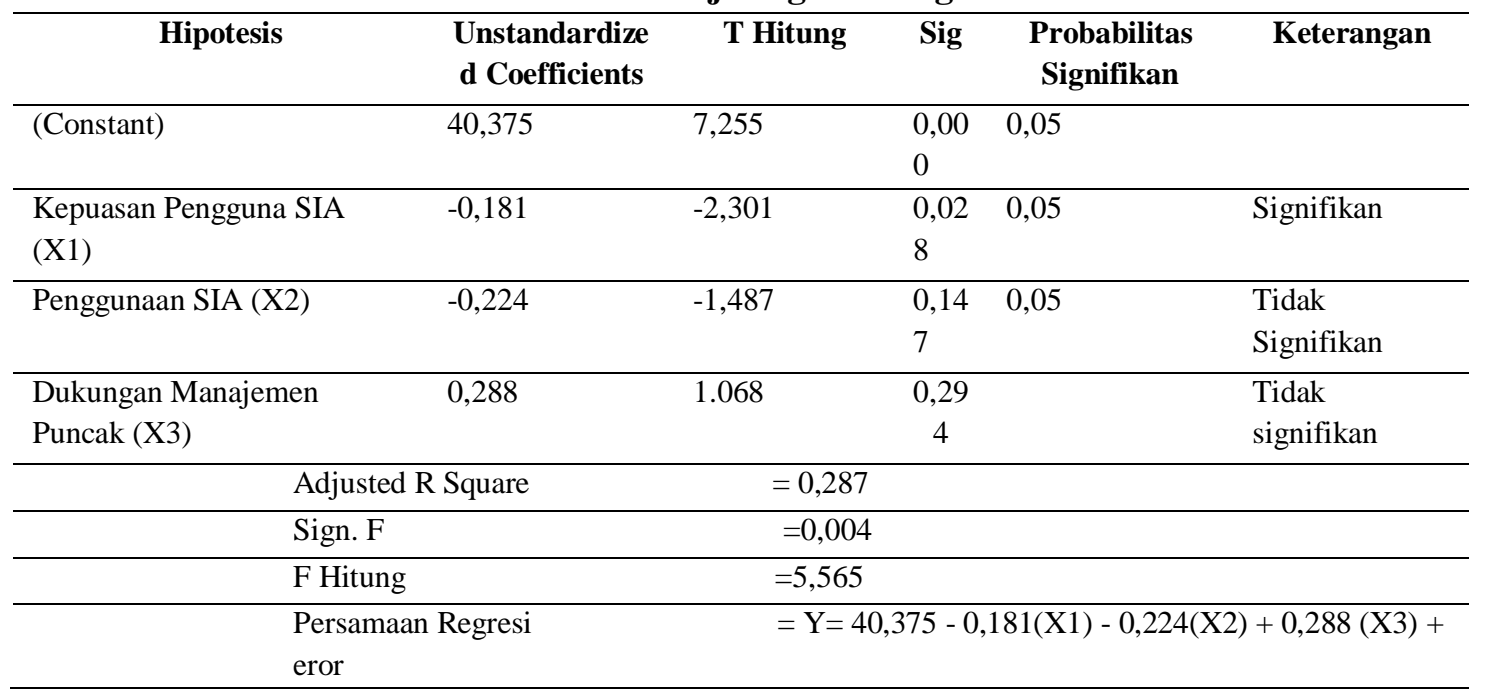

Sumber: Data Primer, diolah, 2017

Tabel 9 di atas menunjukan bahwa variabel kepuasan pengguna SIA (X1) memberikan kontribusi dengan nilai t hitung $-2,301$ sebesar $-0,181$ dengan tingkat signifikan sebesar sebesar 0,028 lebih kecil dari 0,005 $(0,028<0,004)$. Hasil ini dipertegas dengan hasil perhitungan nilai t hitung dan $\mathrm{t}$ tabel. Nilai $\mathrm{t}$ tabel pada taraf signifikan 5\% dan df (derajat kebebasan) $\mathrm{n}-\mathrm{k}=32$ adalah 2,036. Dengan demikian nilai t hitung 2,301>2,036. Hasil pengujian ini menginterpretasikan bahwa hipotesis 1 yang menyatakan bahwa kepuasan pengguna SIA berpengaruh terhadap penerimaan PKB dapat diterima.

Tabel 9 diatas juga menunjukan bahwa variabel penggunaan SIA (X2) memberikan kontribusi dengan nilai t hitung sebesar $-1,487$ sebesar $-0,224$ dengan tingkat 
signifikan sebesar 0,147 lebih besar dari 0,005 (0,147>0,005). Hasil ini dipertegas dengan hasil perhitungan nilai t hitung dan t tabel. Nilai t tabel pada taraf signifikan 5\% dan df (derajat kebebasan) $\mathrm{n}-1=32$ adalah 2,036. Dengan demikian nilai t hitung $1,487<2,036$. Hasil pengujian ini menginterprestasikan bahwa hipotesis 2 yang menyatakan bahwa penggunaan SIA berpengaruh terhadap penerimaan PKB tidak dapat diterima.

Variabel dukungan manajemen puncak (X3) pada tabel 4.9 diatas, memberikan kontribusi dengan nilai t hitung sebesar 1,068 sebesar 0,288 dengan tingkat signifikan sebesar 0,294 lebih besar dari 0,005 (0,294>0,005). Hasil ini dipertegas dengan hasil perhitungan nilai t hitung dan $\mathrm{t}$ tabel. Nilai t tabel pada taraf signifikan 5\% dan df (derajat kebebasan) $n-k=32$ adalah 2,036. Dengan demikian nilai t hitung 1,068<2,036. Hasil pengujian ini menginterprestasikan bahwa hipotesis 3 yang menyatakan bahwa dukungan manajemen puncak berpengaruh terhadap penerimaan PKB tidak dapat diterima.

Nilai probabilitas (Sig F) pada tabel 4.9 diatas, menunjukan angka 0,004 atau dibawah tingkat signifikan 0,05 dan nilai $\mathrm{f}$ hitung 5,565. Hasil ini dipertegas dengan hasil perhitungan nilai $\mathrm{f}$ hitung dan $\mathrm{f}$ tabel. Dalam mencari $\mathrm{f}$ tabel terdapat $2 \mathrm{df}$ yang harus dicari terlebih dahulu yaitu df1 $(\mathrm{N} 1)=\mathrm{k}-1=2$ dan df2 $(\mathrm{N} 2)=\mathrm{n}-\mathrm{k}=32$ sehingga nilai $\mathrm{f}$ tabel pada taraf signifikan 5\% adalah 2,90. Dengan demikian nilai f hitung 5,565>2,90. Hasil pengujian ini menginterprestasikan bahwa hipotesis 4 yang menyatakan bahwa kepuasan pengguna SIA, penggunaan SIA, dan dukungan manajemen puncak secara simultan berpengaruh terhadap penerimaan PKB dapat diterima.

Berdasarkan pada tabel 4.9 diatas hasil uji koefisien determinasi didapat nilai adjusted $\mathrm{R}^{2}$ (koefisien determinasi yang disesuaikan) adalah 0,287 . Hal ini berarti $28,7 \%$ dari variasi penerimaan PKB dapat dijelaskan oleh variabel independen sedangkan sisanya $71,3 \%$ dijelaskan oleh sebab-sebab lain.

\section{A. PEMBAHASAN}

Berdasarkan ringkasan hasil pengujian hipotesis dengan regresi berganda, tujuan penelitian untuk mengetahui: 1) pengaruh kepuasan pengguna SIA terhadap penerimaan $\mathrm{PKB}$; 2) pengaruh penggunaan SIA berpengaruh terhadap penerimaan $\mathrm{PKB} ; 3$ ) pengaruh dukungan manajemen puncak terhadap penerimaan PKB; dan 4) pengaruh kepuasan pengguna SIA, penggunaan SIA, dan dukungan manajemen puncak secara simultan sudah tercapai.

\section{Pengaruh Kepuasan Pengguna SIA terhadap Penerimaan PKB}

Berdasarkan hasil pengujian pada tabel 4.10 menunjukkan bahwa pengaruh kepuasan pengguna SIA berpengaruh terhadap penerimaan PKB. Koefisien regresi variabel kepuasan pengguna SIA (X1) sebesar -0,181 menjelaskan bahwa kepuasan pengguna SIA berpengaruh negatif terhadap penerimaan PKB. Jadi semakin tinggi kepuasan pengguna maka penerimaan akan semakin rendah. Hasil penelitian ini membuktikan bahwa kepuasan pengguna SIA merupakan faktor yang penting dalam penerimaan PKB. Semakin tinggi kepuasan pengguna SIA maka penerimaan PKB akan semakin rendah. Artinya bahwa kepuasan pengguna disini dilihat dari kinerja individu yang menggunakan sebuah sistem karena keberhasilan sebuah sistem tergantung bagaimana sistem itu dijalankan, kemudahan sistem itu bagi para pemakainya dan pemanfaatan teknologi yang digunakan (Goodhue, 1995) dalam (Istianingsih, 2007). 
Theory of Reasoned Action (TRA/Teori Tindakan Beralasan) adalah suatu teori yang berhubungan dengan sikap dan perilaku individu dalam melaksanakan kegiatan. Seseorang akan memanfaatkan sistem informasi dengan alasan bahwa sistem tersebut akan menghasilkan manfaat bagi dirinya. Sheppard et al., (1988) dalam Grace (2011) menyatakan bahwa TRA telah digunakan untuk memprediksi suatu perilaku dalam banyak hal. Dari berbagai model yang telah diteliti, Technology Acceptance Model (TAM/ Model Penerimaan Teknologi) yang diadopsi dari Theory of Reasoned Action (TRA/Teori Tindakan Beralasan) menawarkan sebagai landasan untuk memperoleh pemahaman yang lebih baik mengenai perilaku pemakai dalam penerimaan dan penggunaan sistem informasi Davis, et al., (1989) dalam Grace (2011). Tujuan model ini adalah untuk dapat menjelaskan faktor-faktor utama dari perilaku pengguna teknologi informasi terhadap penerimaan penggunaan teknologi informasi itu sendiri.

Teknologi informasi sangat diyakini mampu memberikan manfaat bagi parapemakai dalam organisasi apapun. Teknologi informasi bermanfaat dalam berbagai macam aktivitas baik operasional maupun manajerial. Dampak nyata penggunaan teknologi informasi saat ini diyakini memberikan manfaat bagi individu maupun organisasi dalam menjalankan fungsi-fungsi manajerial. Jogiyanto (2003) dalam Purwito (2013) menyatakan bahwa penggunaan teknologi infomasi mempunyai empat manfaat yaitu: Untuk meningkatkan efisiensi, yang dapat dicapai dengan PCS (Proses Control System) yang menggantikan manusia dengan teknologi pada proses produksi, meningkatkan efektivitas, yang dapat dicapai dengan Sistem Informasi Manajemen, Decision Support System, Expert System, meningkatkan komunikasi dan kolaborasi, yang dapat dicapai dengan penerapan Office Automation System dan untuk meningkatkan daya kompetisi, dapat dicapai dengan menggunakan Srategic Information System.

Widjajanto ( 2001:314) dalam Purwito (2013) menyatakan bahwa pemanfaatan teknologi informasi memberikan keuntungan kepada manusia dalam melakukan pekerjaannya. Keuntungan tersebut antara lain : Meningkatkan troughput dan efisiensi, khususnya jika volume data yang diolah cukup besar. Throughput adalah ukuran kapasitas sistem mulai dari input sampai output dalam suatu periode tertentu, konversi data dengan menggunakan komputer juga menjanjikan kemudahan, karena bisa melakukan perhitungan secara otomatis, bisa membuat nomor urut secara otomatis, dan verifikasi kecermatan angka-angka data transaksi input dan membandingkan data tersebut dengan data yang sah, komputer mampu menyajikan informasi secara cepat. Selain itu komputer juga mampu memberikan kecermatan yang tinggi dibandingkan dengan manusia. Penggunaan teknologi informasi akan meningkatkan kualitas informasi sehingga akan dapat memperkecil tingkat kesalahan dalam pengambilan keputusan baik tingkat operasional maupun manajerial.

Widjajanto (2001: 25) dalam Purwito (2013) memberikan syarat-syarat agar informasi memiliki kualitas yang baik harus memiliki unsur-unsur berikut ini. Kecermatan dapat didefinisikan sebagai perbandingan antara informasi yang benar terhadap total informasi yang dihasilkan dalam suatu periode. Ukuran kecermatan ini sangat bervariasi, dan amat bergantung pada sifat informasi yang dihasilkan, penyajian yang tepat waktu. Informasi yang terlambat diterima nilai kegunaannya akan lebih rendah, karena keputusan bisnis yang cepat dapat dianggap lebih baik daripada keputusan yang lambat. Dalam persaingan yang tinggi keputusan yang lambat dapat berarti 
memberikan peluang kepada pesaing untuk mengambil keputusan yang baik dan lebih cepat, Kelengkapan. Informasi yang tidak lengkap bisa menimbulkan kesulitan, karena bagian informasi yang hilang boleh jadi merupakan unsur yang kritis. Dengan demikian informasi yang sudah tepat waktu dan cermat dapat dianggap sebagai informasi yang berkualitas. Artinya informasi yang lengkap adalah informasi yang relevan dengan kebutuhan penggunannya, Ringkas. Informasi yang ringkas artinya informasi yang relevan dengan menunjuk pada bidang-bidang penyimpangan terhadap standar atau rencana, merupakan informasi yang banyak diperlukan para manajer.

Sistem Self Assessment (Pemungutan Perpajakan). Pembayaran pajak merupakan perwujudan dari kewajiban kenegaraan dan peran serta wajib pajak untuk secara langsung dan bersama-sama melaksanakan kewajiban perpajakan untuk pembiayaan negara dan pembangunan nasional.

Menurut Vanessa dan Hari (2009) dalam Pancawati (2011) Kemauan membayar pajak. Konsep kemauan membayar pajak (willingness to pay tax) diartikan suatu nilai yang rela dikontribusikan oleh seseorang (yang ditetapkan dengan peraturan) digunakan untuk membiayai pengeluaran umum Negara dengan tidak mendapat jasa timbal (kontraprestasi) secara langsung. Kemauan membayar pajak dipengaruhi oleh beberapa faktor yaitu kondisi sistem administrasi perpajakan suatu negara, pelayanan pada wajib pajak, penegakan hukum perpajakan dan tarif pajak, Devano dan Rahayu (2006) dalam Pacawati (2011).

Kesadaran membayar pajak. Kesadaran wajib pajak dalam membayar kewajiban pajak akan meningkat bilamana dalam masyarakat muncul persepsi positif terhadap pajak. Meningkatnya pengetahuan perpajakan masyarakat melalui pendidikan perpajakan baik formal maupun non formal akan berdampak positif terhadap kesadaran wajib pajak untuk membayar pajak. Karakteristik wajib pajak yang di cerminkan oleh kondisi budaya, sosial, dan ekonomi akan dominan membentuk perilaku wajib pajak yang tergambar dalam tingkat kesadaran mereka dalam membayar pajak. Penyuluhan pajak yang dilakukan secara intensif dan kontinyu akan dapat meningkatkan pemahaman wajib pajak tentang kewajiban membayar pajak sebagai wujud kegotongroyongan nasional dalam menghimpun dana untuk kepentingan pembiayaan pemerintahan dan pembangunan nasional, Suryadi (2006) dalam Pancawati (2011) . Meskipun sistem pemungutan pajak self assessment systemsudah dijalankan. Namun dalam prakteknya sulit berjalan sesuai dengan yang diharapkan atau bahkan disalahgunakan. Hal ini dapat dilihat dari banyaknya wajib pajak yang dengan sengaja tidak patuh, kesadaran wajib pajak yang masih rendah atau kombinasi keduanya, sehingga membuat wajib pajak enggan melaksanakan kewajiban membayar pajak.

Dari berbagai teori datas dapat disimpulkan bahwa kepuasan pengguna dilihat dari individu yang menggunakan teknologi informasi dan sangat diyakini mampu memberikan manfaat bagi para pemakai dalam organisasi apapun tetapi dipandang dari segi perpajakan menunjukan bahwa masih sangat rendah penerimaan karena kesadaran dari wajib pajak yang masih kurang serta sistem pemungutan yang dilihat dari banyaknya wajib pajak yang dengan sengaja tidak patuh, kesadaran wajib pajak yang masih rendah atau kombinasi keduanya.

\section{Pengaruh Penggunaan SIA terhadap Penerimaan PKB}


Berdasarkan hasil pengujian pada tabel 4.10 menunjukkan bahwa penggunaan SIA tidak berpengaruh terhadap penerimaan PKB. Koefisien regresi variabel penggunaan SIA (X2) sebesar -0,224 menjelaskan bahwa penggunaan SIA tidak berpengaruh terhadap penerimaan PKB. Jadi semaki tinggi penggunaan SIA maka penerimaan PKB akan semakin rendah. Hasil penelitian ini membuktikn bahwa seorang pengguna sistem berharap dengan menggunakan sistem tersebut mereka akan memperoleh informasi yang mereka butuhkan dimana sistem ini sangat membantu dalam kemudahan serta keakuratan layanan sistem informasi, menurut Sadin dan Kiew (1996) dalam Istianingsih (2007) sehingga memudahkan juga bagi pembayar pajak dalam pelayanan yang diberikan, tetapi tergantung juga bagi wajib pajak yang sadar akan pentingnya membayar pajak.

Penggunaan sistem informasi akuntansi dalam organisasi menuntutpemakai komputer (user) meningkatkan kemampuannya dalam menggunakan komputer, Sari(2009) dalam Agus et.al (2016). Dengan semakin lancar pengguna atau pemakai komputer (user) maka semakin efektif penerapan sistem informasi di suatu organisasi.Cudanov, et al. (2010) dalam Agus et.al (2016) menyatakan bahwa implementasi informasi dan teknologi komunikasi dipengaruhi oleh ukuran organisasi. Ukuran organisasi perusahaan yang semakin besar dengan didukung oleh sumber daya yang semakinbesar akan menghasilkan sistem informasi yang lebih baik sehingga pemakai akanmerasa puas untuk menggunakan sistem informasi akuntansi yang ada dan akanlebih sering menggunakan sistem yang diterapkan dalam perusahaan.

Menururt Pancawati (2016) Pemahaman Peraturan Perpajakan. Pemahaman wajib pajak terhadap peraturan perpajakan adalah cara wajib pajakdalam memahami peraturan perpajakan yang telah ada. Wajib pajak yang tidak memahami peraturan perpajakan secara jelas cenderung akan menjadi wajib pajak yang tidak taat. Jelas bahwa semakin paham wajib pajak terhadap peraturan perpajakan, maka semakin paham pula wajib pajak terhadap sanksi yang akan diterima bila melalaikan kewajiban perpajakan mereka.

Dari teori diatas dapat disimpulkan bahwa penggunaan sebuah sistem informasi akuntansi menuntut pemakai komputer untuk meningkatkan kemampuan agar semakin efektif penerapan pada suatu organisasi akan tetapi kurang efektif karena tidak didukung oleh penerimaan pajak sebab pemahaman peraturan perpajakan yang tidak secara jelas membuat wajib pajak tidak taat sehingga penerimaan pajak akan rendah.

\section{Pengaruh Dukungan Manajemen Puncak terhadap Penerimaan PKB}

Berdasarkan hasil pengujian pada tabel 4.10 menunjukkan bahwa dukungan manajemen puncak tidak berpengaruh terhadap penerimaan PKB. Koefisien regresi variabel dukungan manajemen puncak (X3) sebesar 0,288 menjelaskan bahwa dukungan manajemen puncak tidak berpengaruh terhadap penerimaan PKB.

Dukungan manajemen puncak merupakan pihak yang bertanggungjawab atas penyediaan pedoman umum bagi kegiatan sistem informasi menurut Hasmi (2004) dalam Septianingrum (2014). Menurut Lau (2004) dalam Dewa (2014), dukungan manajemen puncak adalah perilaku eksekutif yang berhubungan dengan perencanaan sistem informasi, pengembangan dan implementasinya. Manajemen puncak dalam organisasi harus mendapatkan pengetahuan tentang kualitas informasi yang tepat dalam penerapan sistem informasi akuntansi guna meningkatkan kinerja serta membantu organisasi untuk membuat keuntungan. 
Menurut Indra Ismawan (2001) dalam Diani(2016) sistem administrasi perpajakan modern adalah suatu proses reformasi pembaharuan dalam bidang administrasi perpajakan yang dilakukan warga komprehensif, meliputi aspek teknologi informasi yaitu perangkat lunak, perangkat keras dan sumber daya manusia. Aspek teknologi informasi yaitu proses pembaharuan dibidang teknologi informasi yang berkaitan dengan sistem administrasi perpajakan. Berdasarkan dari pengertian diatas, maka dapat dikatakan bahwa sistem administrasi perpajakan modern adalah suatu proses reformasi pembaharuan dalam bidang administrasi perpajakan berupa penyempurnaan atau perbaikan dari kinerja, baik secara individu, kelompok, maupun kelembagaan agar lebih efisien, ekonomis dan cepat.

Berdasarkan teori diatas dapat disimpulkan bahwa dari segi dukungan maka manajemen harus lebih aktif sehingga para karyawan atau pegawai lebih bersemangat untuk bekerja dan manajemen juga mempunyai keahlian dalam menggunakan sebuah sistem sehingga lebih mudah dalam memberi pemahaman dalam menginput data karena keterkaitan antara sistem perpajakan modern dari proses pembaharua dari perbaikan kinerja baik individu, kelompok maupun kelembagaan.

\section{Pengaruh Kepuasan Pengguna SIA, Penggunaan SIA, dan Dukungan Manajemen Puncak terhadap Penerimaan PKB}

Berdasarkan hasil pengujian pada tabel 4.10 menunjukkan bahwa kepuasan pengguna SIA penggunaan SIA, dan dukungan manajemen puncak berpegaruh secara simultan terhadap penerimaan PKB. Koefisien regresi variabel kepuasan pengguna SIA, penggunaan SIA dan dukungan manajemen puncak (X4) sebesar 0,287 menjelaskan bahwa kepuasan pengguna SIA, penggunaan SIA dan dukungan manajemen puncak berpengaruh terhadap penerimaan PKB.

Penelitian ini membuktikan bahwa kepuasan pengguna SIA, penggunaan SIA dan dukungan manajemen puncak merupakan faktor yang mempengaruhi penerimaan PKB sehingga orang (individu), mempunyai kepuasan dalam menggunakan sistem, serta memiliki dukungan manajemen puncak yang kuat dalam melaksanakan tugas untuk mendapatkan hasil penerimaan PKB yang baik.

\section{KESIMPULAN}

Berdasarkan hasil analisis data, dapat disimpulkan sebagai berikut:

1. Kepuasan pengguna SIA berpengaruh signifikan terhadap penerimaan PKB di kantor SAMSAT dan DISPENDA Kalabahi Kabupaten Alor. Kepuasan pengguna SIA yang baik adalah bagaimana pengguna turut serta dalam pengawasan dan memiliki sistem, karena dukungan pengguna dalam implementasi sistem memiliki peranan dalam menunjang keberhasilan sistem informasi itu sendiri;

2. Penggunaan SIA tidak berpengaruh signifikan terhadap penerimaan PKB di kantor SAMSAT dan DISPENDA Kalabahi Kabupaten Alor. Dalam hal ini, penggunaan SIA memang penting dalam penerimaan PKB namun tidak secara langsung mempengaruhi penerimaan PKB dikarenakan pengguna bukan hanya semata-mata meggunakan setiap sistem yang ada, tetapi memahami secara jelas sistem mana yang digunakan dalam menginput data yang dibutuhkan;

3. Dukungan manajemen puncak tidak berpengaruh signifikan terhadap penerimaan PKB. Dalam hal ini, dukungan manajemen puncak penting bagi penerimaan PKB namun tidak secara langsung mempengaruhi penerimaan PKB dikarenakan bukan 
hanya dukungan lisan semata melainkan dukungan langsung atau turut serta dalam menggunakan sistem yang ada; dan

4. Kepuasan pengguna SIA, penggunaan SIA dan dukungan manajemn puncak berpengaruh secara simultan terhadap penerimaan PKB. Hal ini berarti ketiga variabel independen tersebut merupakan faktor-faktor yang mempengaruhi penerimaan PKB. Dengan demikian seorang (individu) harus memiliki rasa puas dalam arti sistem yang ada telah bersifat akurat, mudah dan tepat dalam menggunakan sistem itu serta dukungan dan tindakan penuh dalam sebuah institusi untuk mewujudkan tujuan organisasi.

Penelitian ini memiliki keterbatasan yang mungkin mempengaruhi hasil penelitian yaitu terbatasnya jumlah responden karena jumlah populasi yang tidak besar dan juga keterbatasan variabel independen yang diajukan dalam menguji pengaruh penerimaan pajak kendaraan bermotor sehingga masih dimungkinkan akan ada variabel lain yang dapat mempengaruhi penerimaan pajak kendaraan bermotor.

Berdasarkan hasil penelitian yang telah dilakukan maka diajukan saran antara lain:

1. Penggunaan instrumen penelitian harus lebih disesuaikan dengan institusi/organisasi penerimaan. Penyesuaian instrumen penelitian dapat disesuaikan dengan peraturan, pedoman dengan institusiorganisasi yang dijadikan sampel atau populasi penelitian. Hal ini bertujuan agar hasil penelitian lebih sesuai dengan keadaan yang terjadi pada institusi/organisasi tersebut;

2. Penelitian selanjutnya dapat memperluas wilayah penelitian dan penambahan jumlah sampel pada unit kerja lainnya di SAMSAT dan DISPENDA sehingga hasilnya dapat digeneralisasi; dan

3. Penelitian selanjutnya dapat mengkaji untuk menambah variabel moderasi atau intervening, bukan untuk mengurangi variabel dalam metode penelitian yang digunakan.

\section{DAFTAR PUSTAKA}

Ac, Kesdo, Purwanto. 2013. Analisis kepuasan wajib pajak: pendekatan terhadap penggunaan teknologi informasi dan self assessment. Program Studi Manajemen Universitas Surakarta

Amri, Faisal. 2009. Analisis faktor-faktor yang mempengaruhi kinerja sistem informasi akuntansi. Fakultas Ekonomi Universitas Sumatera Utara.

Bodnar, H Gerge; dan Hopwood, S William. 2004. Sistem informasi akuntansi. Edisis sembilan. Andi. Yogyakarta.

Daman, Agus, Wahyu, Arya; Swardika, Made, Sadha. 2016. Pengaruh keterlibatan pemakai pelatihan, ukuran organisasi dan keahlian pemaa terhadap kinerja sistem informasi akuntansi. Fakultas Ekonomi dan Bisnis Unieritas Udayana.

Diana, Anastasia; \& Setiawati, Lilis. 2011. Sistem informasi akuntansi erancangan proses dan penerapan. Edisi Pertama. Andi. Yogyakarta. 
Febriati. 2011. Analisis sistem pengendalian pemungutan pajak kendaraan bermotor dalam peningkatan PAD. Jurnal ISSN 1693-9093 halaman 165-185. Fakultas Ekonomi Universitas Panca Bakti Pontianak.

Florentiana Agustina. 2016. Analisis istem informasi akuntansi dalam meningkatkan pengendalian internal atas pendapatan. ISSN 2303-1174.

Ghozali, Imam. 2013. Aplikasi multivarite dengan program IBM SPSS 21 update regresi, Cetakan ke VII, hal 105-166. Badan Penerbit Universitas Diponegoro. Semarang.

Hendra, D.P; Setiawanta, Yulita; Setriana, Ira. 2014. Analisis pengaruh keterlibatan pemakai dalam pengembangan sistem informasi, dukungan manajemen puncak, dan formalitas pengembangan sistem informasi terhadap kinerja sistem informasi akuntansi. Jurusan Akuntansi Universitas Dian Nuswantoro Semarang.

Hanifah, Diani, Nur. 2016. Pengaruh kualitas pelayanan pajak dan sistem administrasi perpajakan modern terhadap kepuasan wajib pajak. Program Studi Akuntansi Universitas Komputer Indonesia.

Hardiningsih, Pancawati; Yuliawati, Nila. 2011. Faktor-faktor yang mempengaruhi kemamuan membayar pajak. Program Studi Akuntansi Universitas Stikubang Semarang.

Istianingsih. 2007. Pengaruh kepuasan pengguna sistem informasi terhadap kinerja individu. Fakultas ekonomi Unversitas Mercubuana.

Kurniawan, Panca; Purwanto, Agus. 2006. Pajak daerah dan retribusi daerah di Indonesia. Edisi kedua. Bayumedia publishing. Jawa timur.

Mahadinata,W.P; Wahyuni, M.A; Sinarwati, N.K.2016. Pengaruh penggunaan teknologi informasi, efektivitas sistem iformasi akuntansi, kepercayaan atas sistem informasi akuntansi dan kesesuaian tugas terhadap kinerja perusahaan pada lembaga perkreditan desa. e-journal SI AK. Volume 6 Nomor 3 Tahun 2016.

Mansoer, Faried Widjaja, (2006), Metode Penelitian Bisnis, BMP PascasarjanaMagister

Manajemen, Universitas Terbuka Jakarta.

Mardiasmo. 2009. Perpajakan. Edisi Revisi. Andi. Yogyakarta.

Naressy, Frengky. 2014. Evaluasi sistem informasi akuntansi pendapatan dan penerimaan kas. Journal riset mahasiswa akuntansi. ISSN:23375663. Volume 02, nomor 02. Program Studi Akuntansi Universitas Kanjuruhan Malang.

Novia, Dini; Mulyawan, Ali. 2016. Aplikasi pembayaran pajak kendaraan bermotor online berbasis WEB. Jurnal ISSN 2442-4943.

Oktaviana, Dian, Lari. 2013. Analisis faktor-faktor yang mempengaruhi kepuasan pengguna sistem informasi terhadap kinerja individu. Jurusan Akuntansi Universitas Surakarta.

Pasaribu, Umi. 2011. Analisis penerapan elektronic data processing dalam sistem informasi akuntansi.Universitas Sultan Syarif Kasim.

Pudyatmoko, Sri Y. 2009. Hukum pajak. Edisi empat. Andi. Yogyakarta.

Puspitawati, Lilis; \& Anggadini, D Sri. 2011.Sistem Informasi Akuntansi.Edisi Pertama.Graha Ilmu.Yogyakarta. 
Rahmawati, Aulia; Pratomo, Dudi. 2015. Pengaruh partisipasi pengguna sistem informasi dan kemampuan pengguna sistem informasi terhadap kinerja sistem informasi akuntansi. Program Studi Akuntansi Universitas Telkom.

Ratnasari. 2016. Analisis penerimaan pajak kendaraan bermotor.jurnal progres ekonomi pembangunan. Volume 1 nomor 1 2016.ISSN 2502-5171.

Rivaningrum Ajeng. 2015. Faktor-faktor yang mempengaruhi kinerja sistem informasi akuntansi. Program Studi Akuntansi Universitas Negeri Semarang.

Nurkasih, Rosi, Rahayu. 2016. Pengaruh konflik peran, komitmen organisasi, pemahaman good governance dan budaya organisasi terhadap kinerja pemeriksa BPK perwakilan propinsi NTT. Jurusan Akuntansi Universitas Muhammadiyah Kupang.

Rumney, B Marshal; \& Steinbart, John Paul. 2006. Accounting Information System. Edisi sembilan. Salemba. Jakarta.

Saefulloh, P.Indra. 2014. Perancangan sistem informasi pembayaran pajak kendaraan beroda dua. Program Studi sistem Informasi Bandung.

Septianingrum. P.A. 2014. pengaruh dukungan management, kemampuan pengguna, serta adanya pelatihan dan pendidikan pengguna terhadap kinerja sistem informasi akuntansi. Program Studi Akuntansi Universitas Negeri Yogyakarta

Siahan,M Pahal . 2010. Pajak daerah dan retribusi daerah. Edisi revisi kedua. PT Rajagrafindo Persada. Jakarta.

Sugiyono. (2014). Metode Penelitian Kuantitatif kualitatif dan $R \& D$. Alfabeta.Bandung.

Sugiyono, (2009). Metode Penelitian Kuantitatif kualitatif dan $R \& D$, , Bandung,

Alfabeta

Suratini, Eka. Sinarwati, Kadek. Atmadja, Tungga. 2015. Pengaruh efektivitas sistem informasi akuntansi dan penggunaan teknologi informasi akuntansi terhadap kinerja individual.e-journal SI AK.Volume 3 Nomor 2. Universitas Pendidikan Ganesha Singaraja

Tungka, Melinda; Sabijono, Harijanto. 2015. Analisis perhitungan dan pencatatan pajak kendaraan bermotor. Jurusan Akuntansi Universitas Sam Ratulangi Manado

Winarso, Widi. 2015. Analisis penerimaan pajak kendaraan bermotor terhadap pendapatan asl daerah. Semiar Nasional Inovasi dan Tren (SNIT) 2015.

Wisudiawan Ary. 2013. Pengaruh partisipasi pengguna dan kepuasan pengguna terhadap sistem informasi akuntansi.

Wower, Utami; Widhiyani, Sari. 2012. Penilaian efektivtas penerapan sistem informasi akuntansi berbasis komputer. Fakultas Ekonomi Uiversitas Udayana.

Yusuf, Akbar. 2013. Hubungan antara modal intelektual dengan nilai pasar dan kinerja keuangan perusahaan di BEI. Makasar. Program Pascasarjana Ilmu Akuntansi Universitas Hasanudin. 